\title{
THE FEATURES OF ATHEROSCLEROTIC PROCESS DEVELOPMENT AND ACUTE CORONARY SYNDROME COURSE IN PATIENTS WITHOUT DYSLIPIDEMIA
}

\author{
Valeriia Vataha \\ Department of Family Medicine \\ Shupik National Medical Academy of Postgraduate Education \\ 9 Dorogozhytska str., Kyiv, Ukraine, 04112 \\ valeri.vataga@online.ua
}

\begin{abstract}
The aim is to study the conditions of appearance and the features of course of the acute coronary syndrome (ACS) in patients with normal rates of lipid metabolism and to assess the influence of additional risk factors (uinary acid, C-reactive protein, fibrinogen) on the development of atherosclerotic process by assessment of surrogate markers of atherosclerosis the thickness of intima-media complex (TIMC) of carotid arteries (CA), the presence of atherosclerotic plaque (AP) in CA, the value of ankle-brachial index $(\mathrm{ABI})$ ) in patients with ACS without dyslipidemia (DLP).

Materials and methods. The study included 66 patients without DLP ( 50 men and 16 women, the mean age $-53,7 \pm 10,6$ years) with ACS, divided in groups depending on its forms: 1 group - patients with instable angina (IA), 2 group - patients with myocardium infraction (MI) without ST segment elevation and 3 group - patients with MI with ST segment elevation. The level of serum acid, C-reactive protein, fibrinogen in blood serum were detected and ultrasound examination of CA with detection of CA TIMC, presence of atherosclerotic plaque and measuring of arterial pressure on upper and low extremities with ABI calculation was carried out.

Results. Among examined patients MI with ST segment elevation was diagnosed in 33 persons (50,0\%); MI without ST segment elevation - in $18(27,3 \%)$ and IA - in 15 (22,7 \%). The complicated ACS was observed in $20(30,30 \%)$ persons. The value of CA TIMC among patients with MI with ST segment elevation was reliably higher than in patients with MI without ST segment elevation $(p<0,001)$, and ABI was reliably lower in persons with MI and ST segment elevation $(p<0,05)$ and IA $(p<0,05)$ than in patients with MI without ST segment elevation. Correlative analysis demonstrated the interconnection between the levels of inflammation indicators (C-reactive protein, fibrinogen) in the blood serum and the value of CA TIMC and ABI.

Conclusions. The persons without DLP need additional examination (detection of C-reactive protein, fibrinogen levels in blood serum, ultrasound of CA and detection of ABI) for more precise evaluation of ACS risk.
\end{abstract}

Keywords: acute coronary syndrome, absence of dyslipidemia, risk factors.

\section{Introduction}

The disorder of lipid metabolism - dyslipidemia (DLP) - is verified etiological factor of atherosclerosis that independently or together with other risk factors of cardiovascular diseases leads to the heavy complications in cardiovascular system [1]. Atherosclerosis of coronary vessels is a main cause of ischemic heart disease (IHD) [2].

IHD can be manifested in both acute and chronic forms that, in their turn, lead to the decrease of life quality, invalidism and untimely death. And although it is well-known, that the risk of IHD increases with age, the persons of active working age, especially men, most often suffer from this pathology [3]. Moreover, in many cases the disease is manifested by acute coronary syndrome (ACS) that includes myocardium infraction (MI) with ST segment elevation, MI without ST segment elevation and instable angina (IA) and is dangerous for life [4-6].

It is well-known, that the increase of general cholesterol level correlates with increase of IHD morbidity and mortality level. But according to the literary data [7-10] the share of persons, in whom ACS developed on the background of normal rates of lipid metabolism is near $50 \%$, and they are mainly related to the groups of low and moderate cardiovascular risk according to SCORE, so at the initial link of medical-sanitary help this contingent is often left without proper attention and does not receive initial prophylaxis.

Taking into account the fact that atherosclerosis is a system disease of vessels and their construction is unchangeable on different links, several scientists assume that the intensity of atherosclerotic processes in coronary arteries can be evaluated by indirect way by assessment of carotid 
arteries state, and non-invasive ultrasound methods with detection of surrogate markers of atherosclerosis (the thickness of intima-media complex (TIMC) of carotid arteries (CA), the presence of atherosclerotic plaque (AP) in CA, the value of ankle-brachial index (ABI)) are used for it [11-14].

Many efforts of the modern medical science are devoted to the search of risk factors and predicators of both acute and chronic forms of IHD that could help at initial link of health protection to recognize persons with increased risk of aforesaid pathology development in proper time, to carry out timely prophylaxis and prevent cardiovascular complications [15-17]. Besides wellknown traditional risk factors of IHD, the role of additional biochemical risk factors and surrogate markers of atherosclerosis in prognostication of cardiovascular complications is studied. But these studies were carried out in general population, where the one of most important verified IHD risk factors is dyslipidemia. The recommendations as to the initial prophylaxis were elaborated for persons with dyslipidemia, whereas there is no any recommendations for persons without it that are often related to the zones of low and moderate risks.

Although there are many works [18-20], devoted to the features of ACS course on the background of different concomitant diseases, the question about appearance and course of acute coronary syndrome in persons with normal rates of lipid metabolism remains insufficiently studied.

\section{Aim of research}

To study the conditions of appearance and the features of course of the acute coronary syndrome (ACS) in patients with normal rates of lipid metabolism and to assess the influence of additional risk factors (urinary acid, C-reactive protein, fibrinogen) on the development of atherosclerotic process by assessment of surrogate markers of atherosclerosis: the thickness of intima-media complex (TIMC) of carotid arteries (CA), the presence of atherosclerotic plaque (AP) in CA, the value of ankle-brachial index (ABI)) in patients with ACS without dyslipidemia (DLP).

\section{Materials and methods}

The research was carried out at the department of family medicine of National academy of postgraduate education, named after P.L. Shupyk on the base of MI KRC "Kyiv regional cardiological clinic". Totally there were examined 66 persons (50 men, 16 women) 22-75 years old (mean age - 53,7 $\pm 10,6$ years) with ACS, developed on the background of normal rates of lipid metabolism (mean levels of general $\mathrm{Ch}$ and $\mathrm{Ch}$ of IDL were 4,21 $\pm 0,08 \mathrm{mmol} / 1$ and 2,53 $\pm 0,03 \mathrm{mmol} / \mathrm{l}$ respectively). Patients were divided in groups, depending on ACS form: 1 group - patients with IA (15 persons), 2 group - patients with MI without ST segment elevation (18 persons) and 3 group patients with MI with ST segment elevation (33 persons). For more detail study of the features of ACS course in persons without DLP patients were additionally divided by age (according to WHO age classification (2014)) and sex. Before the start of research no one of examined persons took lipid-decreasing drugs or biologically active additives (omega-3, polyunsaturated fatty acids and so on) that could influence the results of research. All patients underwent complex general clinical, laboratory (general blood analysis, detection of lipid spectrum, urinary acid, C-reactive protein, fibrinogen in blood serum) and instrumental (measuring of arterial pressure on upper and low extremities with detection of ankle-brachial index (ABI) using portative Doppler sound indicator of blood flow and ultrasound of carotid arteries (CA) with detection of TIMC, presence of atherosclerotic plaque in CA) examinations. The nerve-emotional condition of patients was evaluated using hospital anxiety and depression scale (HADS), intended for initial detection of anxiety and depression in patients (screening) in general medical practice. The provoking factors, considered to be connected with ACS (stress, hypertension stroke, physical loads and so on) were studied.

Statistical processing of the data was carried out using packages of Microsoft Excel 2013 and STASTISTICA 10.0 software.

\section{Results of research}

Among patients with ACS, included in the research MI with ST segment elevation was diagnosed most often (33 persons, 50,0 \%); MI without ST segment elevation and IA - in 18 (27,3\%) 
and $15(22,7 \%)$ patients respectively. The frequency of revelation of different forms of ACS depending on age is presented in the Table 1.

Table 1

The frequency of revelation of different forms of ACS depending on age

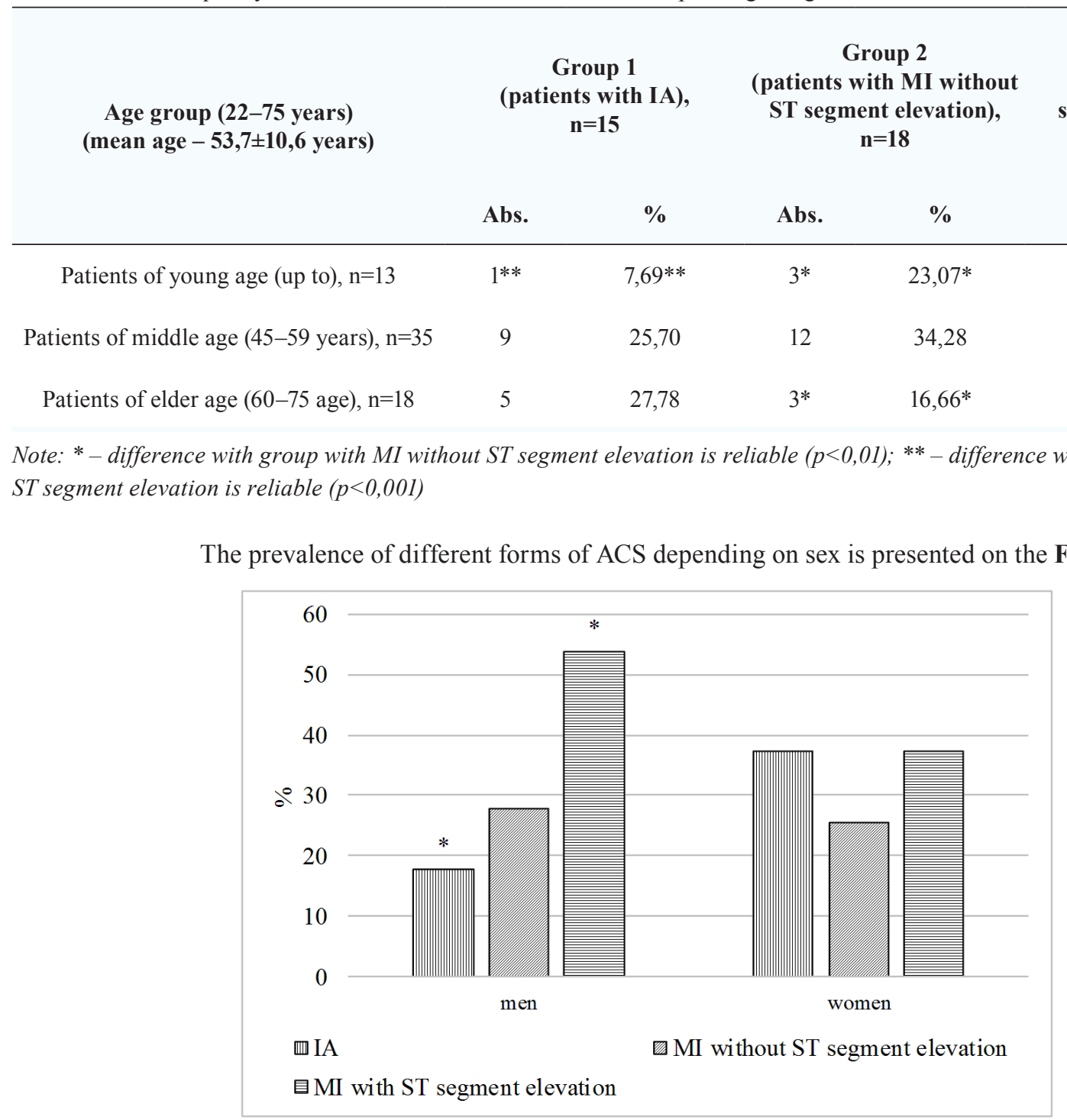

Fig. 1. The prevalence of different forms of ACS depending on sex in patients without DLP:

$*$ - difference between patients of different sex is reliable $(\mathrm{p}<0,05)$

Stress was considered as most often provoking factor of ACS development (36 persons, $54,55 \%)$. The beginning of disease was connected with physical loads in 15 persons $(22,73 \%)$, with hypertension stroke - in 13 persons $(19,69 \%)$, with other causes - 2 persons $(3,03 \%)$.

ACS developed on the background of preliminary diagnosed IHD in 11 persons $(16,67 \%)$, moreover in 7 (63,63\%) of them ACS was manifested as repeated MI and ran with complications (4 persons, 57,14\%). Among examined patients in 11 persons (16,67\%) ACS developed on the background of existing chronic IHD, other 44 patients $(83,33 \%)$ had no IHD in anamnesis. Among patients with chronic IHD in anamnesis, the repeated MI was observed in 7 (63,63\%) with complications in most cases (4 persons, $57,14 \%$ ). 
By localization, MI of front localization occurred in 30 patients $(58,83 \%)$, of back one - in $21(41,17 \%)$. The prevalence of MI by localization among patients with ACS without DLP is presented on the Fig. 2.

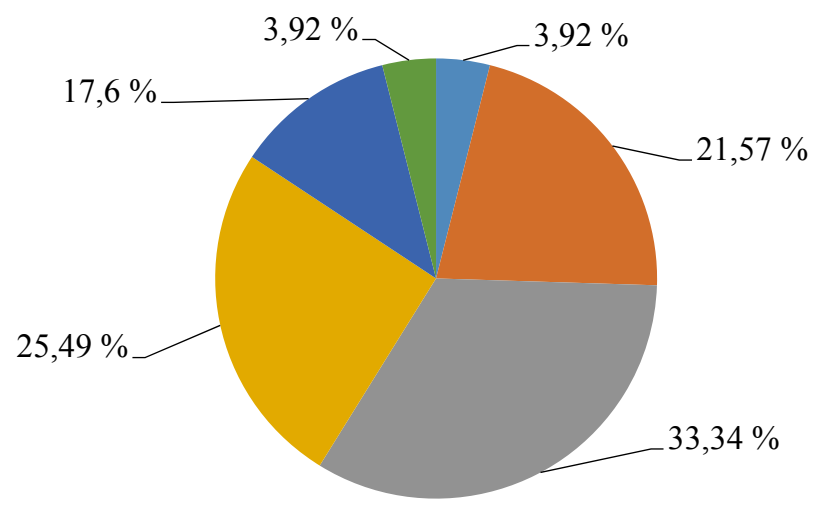

$$
\begin{aligned}
& \text { - front-septal } \quad \text { front-septal-apical } \quad \text { spread front }
\end{aligned}
$$

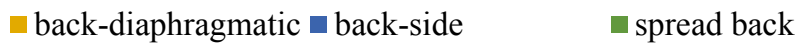

Fig. 2. The prevalence of MI by localization among patients with ACS without DLP

In the structure of ACS complications prevailed the ones, connected with electric instability of myocardium (arrhythmia and block) - 65,0 \% (13 persons). The disorders of heart rhythm were most often manifested as ventricular disorders: ventricular extrasystole (4 persons, 20,0\%) and ventricular tachycardia (3 persons, 15,0 \%), observed at spread front MI. Among over-ventricle disorders were registered the paroxysms of atriums fibrillation in $3(15,0 \%)$ patients. Atrium-ventricular block of III degree was revealed at MI of back-diaphragmatic localization (2 persons, 10,0 \%). Complete block of the left branch of His bundle as ACS complication appeared in $1(5,0 \%)$ patient. Mechanical complications, manifested as early post-infraction dilatation and formation of the left ventricle aneurism appeared in 3 (15,0\%) patients; other mechanical complications of ACS such as the rupture of free wall, inter-ventricle septum, mitral regurgitation, intra-abdominal thrombus-formation were not observed. Among hemodynamic disorders in 1 (5,0\%) patient was observed the acute left ventricular failure. The most often combinations were association of acute left ventricular failure with different types of arrhythmias and blocks, observed in $3(15,0 \%)$ patients with complicated ACS.

The complicated ACS was observed in 20 (30,30\%) persons with ACS, among them $15(30,00 \%)$ men and $5(31,25 \%)$ women. Mi with ST segment elevation ran with complications in 14 patients $(42,4 \%$ of cases), MI without ST segment elevation - in $5(27,78 \%)$ and IA - in $1(6,67 \%)$.

The analysis of frequency of traditional IHD RF such as complicated heredity, excessive body mass/obesity, hypodynamia, smoking, alcohol abuse, stress, arterial hypertension, diabetes mellitus type 2 depending on ACS form did not reveal the reliable difference in patients of both sexes. The characteristic of additional IHD risk factors among patients with different ACS forms is presented in the Table 2.

The assessment of coronary channel state was carried out using coronaroventriculography of 45 patients with ACS. Just among these persons the detail analysis of interconnection between the values of peripheral and coronary vessels state was carried out. According to coronaroventriculography data, the intact vessels were revealed in 2 (4,44\%) persons with ACS, one-vessel injury in $13(28,89 \%)$, two-vessel - in $14(31,11 \%)$ and multi-vessel - in $16(35,56 \%)$.

The direct correlation was established between the number of injured coronary vessels and age $(r=0,49, p<0,05)$, frequency of repeated MI $(r=0,31, p<0,05)$, TIMC $(r=0,55, p<0,05)$, presence 
of atherosclerotic plaque $(r=0,52, p<0,05)$ and reverse connection with $A B I(r=-0,42, p<0,05)$. The mean values of age and surrogate markers of atherosclerosis depending on the number of injured vessels are presented in the Table 3.

Table 2

The characteristic of additional IHD risk factors among patients with different ACS forms

\begin{tabular}{|c|c|c|c|c|}
\hline Risk factor & $\begin{array}{c}\text { Group } 1 \\
\text { (patients with IA), } \\
\mathbf{n}=15\end{array}$ & $\begin{array}{c}\text { Group 2 } \\
\text { (patients with MI without ST } \\
\text { segment elevation), } \\
\text { n=18 }\end{array}$ & $\begin{array}{c}\text { Group 3 } \\
\text { (patients with MI with ST } \\
\text { segment elevation), } \\
\mathbf{n}=\mathbf{3 3}\end{array}$ & $\mathbf{p}$ \\
\hline C-reactive protein, $\mathrm{mg} / \mathrm{l}$ & $7,46 \pm 3,43$ & $8,70 \pm 6,08$ & $13,44 \pm 4,31$ & $\begin{array}{c}\mathrm{p} 1,3<0,001 \\
\mathrm{p} 2,3<0,05\end{array}$ \\
\hline $\begin{array}{l}\text { Urinary acid, } \mathrm{mmol} / \mathrm{l} \\
\text { - men } \\
\text { - women }\end{array}$ & $\begin{array}{l}345,9 \pm 19,2 \\
314,9 \pm 28,1\end{array}$ & $\begin{array}{l}358,7 \pm 23,9 \\
348,2 \pm 45,2\end{array}$ & $\begin{array}{l}383,5 \pm 17,2 \\
336,5 \pm 28,2\end{array}$ & \\
\hline Fibrinogen, $g / 1$ & $3,13 \pm 1,13$ & $3,07 \pm 1,31$ & $3,43 \pm 1,25$ & \\
\hline ABI & $1,01 \pm 0,12$ & $1,10 \pm 0,12$ & $1,02 \pm 0,13$ & $\begin{array}{l}\text { p1,2<0,05 } \\
\text { p2,3<0,05 }\end{array}$ \\
\hline TIMC, mm & $1,08 \pm 0,16$ & $0,96 \pm 0,16$ & $1,13 \pm 0,15$ & $\begin{array}{c}\mathrm{p} 1,3<0,001 \\
\mathrm{p} 1,2<0,05\end{array}$ \\
\hline $\begin{array}{l}\text { AP presence, } \\
\text { number of persons }(\%)\end{array}$ & $5(33,3 \%)$ & $4(22,2 \%)$ & $15(45,5 \%)$ & $\mathrm{p} 2,3<0,05$ \\
\hline
\end{tabular}

Table 3

Surrogate markers of atherosclerosis depending on the number of injured coronary vessels $(\mathrm{M} \pm \mathrm{SD})$

\begin{tabular}{|c|c|c|c|c|}
\hline Parameter & $\begin{array}{l}\text { Intact vessels, } \\
\quad \mathbf{n}=2\end{array}$ & $\begin{array}{c}\text { One-vessel injury, } \\
n=13\end{array}$ & $\begin{array}{c}\text { Two-vessel injury, } \\
n=14\end{array}$ & $\begin{array}{c}\text { Multi-vessel injury, } \\
n=16\end{array}$ \\
\hline Age, years & $41,00 \pm 26,87$ & $44,07 \pm 6,81$ & $55,43 \pm 11,01^{* *}$ & $56,31 \pm 6,86^{* *}$ \\
\hline ABI, left leg & $1,16 \pm 0,04$ & $1,11 \pm 0,05$ & $1,02 \pm 0,12^{* \#}$ & $0,98 \pm 0,15^{* \#}$ \\
\hline $\mathrm{ABI}$, right leg & $1,16 \pm 0,09$ & $1,10 \pm 0,04$ & $0,98 \pm 0,13^{* \#}$ & $1,00 \pm 0,14^{* \#}$ \\
\hline TIMC, mm & $0,85 \pm 0,21$ & $0,96 \pm 0,11$ & $1,11 \pm 0,17^{* \#}$ & $1,16 \pm 0,12^{* * \#}$ \\
\hline $\begin{array}{c}\text { AP presence, } \\
\text { number of persons }(\%)\end{array}$ & - & - & $7(50,0 \%)$ & $10(62,5 \%)$ \\
\hline
\end{tabular}

Note: ${ }^{*}-p<0,05,{ }^{*}-p<0,001$ - difference with group of patients with one-vessel injury is reliable; \#-difference with group of patients with intact vessels is reliable $(p<0,05)$

For more precise study of interconnections between additional IHD risk factors and atherosclerosis risk factors among examined patients the correlative analysis was carried out. It helped to establish the direct connection of moderate force between $\mathrm{C}$-reactive protein and fibrinogen levels $(\mathrm{r}=0,45, \mathrm{p}<0,05), \mathrm{C}$-reactive protein level and TIMC $(\mathrm{r}=0,46, \mathrm{p}<0,01), \mathrm{C}$-reactive protein level and 
presence of atherosclerotic plaque $(\mathrm{r}=0,36, \mathrm{p}<0,01)$, reverse connection of moderate force between C-reactive protein level and ABI $(r=-0,36, p<0,01), A B I$ and presence of atherosclerotic plaque $(r=-0,49, p<0,01)$, significant reverse connection - between the values of TIMC and ABI $(r=-0,63$, $\mathrm{p}<0,01)$; strong direct connection was established between TIMC and presence of atherosclerotic plaque $(\mathrm{r}=0,46, \mathrm{p}<0,01)$.

\section{Discussion of the results of research}

At the analysis of frequency of revelation of the different ACS forms depending on age, in patients up to 45 years MI with ST segment elevation developed reliably more often than the one without ST segment elevation and IA. And although MI with ST segment elevation occupied the leading positions among the prevalence of different ACS forms in patients on any age, some differences were observed in the structure of revelation of different ACS forms depending on age. Thus, among patients of middle age the frequency of revelation of different ACS forms did not reliably differ from each other, all forms of ACS occurred with almost equal frequency. In persons of middle and elder age was observed the tendency to increase of IA cases comparing with persons of the young age.

At the analysis of frequency of revelation of the different ACS forms depending on age among female persons all ACS forms occurred evenly, whereas for male persons the most frequent ACS form was MI with ST segment elevation.

In general on the background of normal lipid metabolism rates ACS developed without preceding IHD that can testify to insufficient attention to the IHD risk factors correction of patients themselves and doctors of initial link of medical-sanitary help.

The complications at MI with ST segment elevation occurred more often than at MI without ST segment elevation and IA that can be conditioned by more area of myocardium lesion at MI with ST segment elevation.

At the analysis of frequency of traditional risk factors of IHD depending on ACS form the reliable difference in patients of both sexes was not revealed that indicates the significant influence of additional risk factors of IHD on formation of myocardium lesion in persons without dyslipidemia.

At the analysis of additional risk factors of IHD among patients with different ACS forms the highest levels of C-reactive protein, fibrinogen, TIMC value, frequency of atherosclerotic plaques were revealed in patients of group with MI with ST segment elevation that can indicate the pathogenetic connection between the additional risk factors and the development of more severe atherosclerotic process and myocardium lesion even at DLP absence.

The correlative analysis revealed reliable difference between CA TIMC among patients with MI with ST segment elevation and MI without ST segment elevation $(p<0,001)$, that testifies to the more intensity of atherosclerosis in patients with MI with ST segment elevation.

ABI was reliably lower in patients with MI with ST segment elevation $(p<0,05)$ and IA $(p<0,05)$ comparing with patients with MI without ST segment elevation that is connected with system atherosclerotic changes in these subgroups of patients.

According to coronaroventriculography data, despite DPL absence, in patients with ACS are observed the expressed atherosclerotic changes with injury of two and more coronary vessels, moreover patients with intact coronary arteries and one-vessel injuries have reliably less changes of peripheral vessels and CA according to assessment of surrogate markers than patients with twoand multi-vessel injury of coronary channel.

So, at comparison of coronary vessels state (according to CVG results) with peripheral vessels state (according to CA ultrasound) the system character of atherosclerotic process and its connection with inflammatory one was proved.

\section{Conclusions}

1. ACS on the background of dyslipidemia absence (normal rates of lipid metabolism) most often runs as MI with ST segment elevation. 
2. The most often provoking factor of ACS in persons with normal rates of lipid metabolism is stress.

3. ACS that appears in persons without DLP is the first manifestation of IHD.

4. In the structure of ACS complications prevail ones, connected with electric instability of myocardium (arrhythmias, blocks).

5. The highest levels of C-reactive protein, fibrinogen, TIMC value, frequency of atherosclerotic plaques were revealed in patients of group with MI with ST segment elevation that can indicate the pathogenetic connection between the additional risk factors and the development of more severe atherosclerotic process and myocardium injury even at DLP absence.

6. The persons without DLP need additional examination (detection of C-reactive protein, fibrinogen levels in blood serum, ultrasound of CA and detection of $\mathrm{ABI}$ ) for more precise evaluation of ACS risk.

\section{References}

[1] Kemm, A. D., Lyusher, T. F., Serrius, P. V. (Eds.) (2011). Bolezni serdtsa i sosudov. Rukovodstvo Evropeyskogo obschestva kardiologov. Moscow: GEOTAR-Media, 1480.

[2] Mikropulo, I. R., Maslennikova, N. O., Prihodko, V. M. (2011). Profilaktika sertsevo-sudinnogo riziku: chi varto chekati soroka rokiv. Mistetstvo likuvannya, 3, 117-122.

[3] Lipovetskiy, B. M. (2012). Dislipidemii, ateroskleroz i ih svyaz s ishemicheskoy boleznyu serdtsa i mozga. Saint Petersburg: Jeko-Vektor, 130.

[4] Skopets, I. S., Vezikova, N. N., Marusenko, I. M., Malygin, A. N. (2012). Ostryiy koronarnyiy sindrom: kompleksnyiy vzglyad na problemu, znachenie gospitalnogo i ambulatornogo etapov lecheniya patsientov. Arhiv vnutrenney meditsinyi, 3, 58-64.

[5] Al-Murayeh, M. A., Al-Masswary, A. A., Dardir, M. D., Moselhy, M. S., Youssef, A. A. (2012). Clinical presentation and short-term outcome of acute coronary syndrome in native young Saudi population. Journal of the Saudi Heart Association, 24 (3), 169-175. doi: 10.1016/j.jsha.2012.03.001

[6] Jamil, G., Jamil, M., AlKhazraji, H. et. al. (2013). Risk factor assessment of young patients with acute myocardial infarction. American Journal of Cardiovascular Disease, 3 (3), 170-174.

[7] Andrikopoulos, G., Tzeis, S., Mantas, I. et. al. (2012). Epidemiological characteristics and in-hospital management of acute coronary syndrome patients in Greece: results from the TARGET Study. Hellenic Journal of Cardiology, 53, 33-40.

[8] Rodríguez-Roca, G. C., Rodríguez-Padial, L., Alonso-Moreno, F. J., Romero-Gutiérrez, A., Akerström, F., Segura-Fragoso, A. et. al. (2013). Perfil lipídico en pacientes ingresados por síndrome coronario agudo en España: datos del área sanitaria de Toledo entre los años 2005 y 2008. SEMERGEN - Medicina de Familia, 39 (6), 298-303. doi: 10.1016/j.semerg.2012.11.001

[9] Korolyuk, O., Radchenko, O. (2009). Gipoholesterolemiya pri gostromu koronarnomu sindromi: prognostichne znachennya, osoblivosti perebigu, suputni nespriyatlivi faktori (oglyad literaturi ta vlasni sposterezhennya). Medichna gidrologiya ta reabilitatsiya, 2 (7), 106-116.

[10] Puricel, S., Lehner, C., Oberhänsli, M., Rutz, T., Togni, M., Stadelmann, M. et. al. (2013). Acute coronary syndrome in patients younger than 30 years - aetiologies, baseline characteristics and long-term clinical outcome. Swiss Medical Weekly, 143, 138-146. doi: 10.4414/smw.2013.13816

[11] Weber, L. A., Cheezum, M. K., Reese, J. M., Lane, A. B., Haley, R. D., Lutz, M. W., Villines, T. C. (2015). Cardiovascular Imaging for the Primary Prevention of Atherosclerotic Cardiovascular Disease Events. Current Cardiovascular Imaging Reports, 8 (9), 36. doi: 10.1007/s12410-015-9351-Z

[12] Zuo, G., Zhang, M., Jia, X., Zheng, L., Li, Y., Zhao, H. et. al. (2014). Correlation Between Brachial-Ankle Pulse Wave Velocity, Carotid Artery Intima-Media Thickness, Ankle-Brachial Index, and the Severity of Coronary Lesions. Cell Biochemistry and Biophysics, 70 (2), 1205-1211. doi: 10.1007/ s12013-014-0043-0 
[13] Kartashova, A. (2008). Subklinicheskiy ateroskleroz. Chto myi mozhem sdelat na etom etape? Medicine Review, 3 (03), 22-26.

[14] Bots, M. L., Grobbee, D. E., Hofman, A.,Witteman, J. C. M. (2005). Common Carotid Intima-Media Thickness and Risk of Acute Myocardial Infarction: The Role of Lumen Diameter. Stroke, 36 (4), 762-767. doi: 10.1161/01.str.0000158924.71069.94

[15] Chen, L. (2012). Serum uric acid in patients with acute ST-elevation myocardial infarction. World Journal of Emergency Medicine, 3 (1), 35-39. doi: 10.5847/wjem.j.issn.1920-8642.2012.01.006

[16] Tatli, E., Ozcelik, F., Aktoz, M. (2009). Plasma fibrinogen level may predict critical coronary artery stenosis in young adults with myocardial infarction. Cardiology Journal, 4 (16), 317-320.

[17] Rodondi, N., Marques-Vidal, P., Butler, J., Sutton-Tyrrell, K., Cornuz, J. et. al. (2010). Markers of Atherosclerosis and Inflammation for Prediction of Coronary Heart Disease in Older Adults. American Journal of Epidemiology, 171 (5), 540-549. doi: 10.1093/aje/kwp428

[18] Strojek, K., Raz, I., Jermendy, G., Gitt, A. K., Liu, R., Zhang, Q. et. al. (2016). Factors Associated With Cardiovascular Events in Patients With Type 2 Diabetes and Acute Myocardial Infarction. The Journal of Clinical Endocrinology \& Metabolism, 101 (1), 243-253. doi: 10.1210/jc.2015-1962

[19] Rhee, J.-W., Wiviott, S. D., Scirica, B. M., Gibson, C. M., Murphy, S. A., Bonaca, M. P. et. al. (2014). Clinical Features, Use of Evidence-Based Therapies, and Cardiovascular Outcomes Among Patients With Chronic Kidney Disease Following Non-ST-Elevation Acute Coronary Syndrome. Clinical Cardiology, 37 (6), 350-356. doi: 10.1002/clc.22253

[20] Agoşton-Coldea, L., Mocan, L., Rusu, D. (2008). The impact of the metabolic syndrome on the patients with acute coronary syndrome. Romanian Journal of Internal Medicine, 46 (1), 55-62. 